In summary: the War Powers Resolution, as it has operated, is not faithful to its stated purposes. It has not been conducive either to decisive confrontation or to cooperation between the branches. This failure owes something to a congressional misperception of what legislation can accomplish. Laws cannot be self-executing in the sense of compelling the Executive or, for that matter, the Congress to carry their purpose into operation. When a law requires the President to act in accordance with established procedures and criteria, four institutions are available to buttress the law's mandate and to urge compliance: the Congress itself, the judiciary, the Treasury and public opinion. Each of these has some persuasive capability, yet each is difficult to mobilize in a crunch. Clarity and simplicity of legislated standards and automaticity of legislated procedures are the means by which Congress may yet persuade the President to rely more on consultation and codetermination and less on "thaumaturgic invocation."

\title{
War Powers: The Operational Code of Competence
}

\section{By W. Michael Reisman*}

Wholly apart from the questions of whether and under what circumstances major coercion is permissible under international law and whether minor coercion, including threats, is lawful, there is a broad and deep national consensus that the United States should continuously develop a military capacity sufficient for a range of contingencies and maintain it in a state of readiness. ${ }^{1}$ The consensus has been far less certain with regard to who will decide, and how, to initiate and use this capacity, at varying intensities. The original terms of the Constitution have been invoked by partisans of opposing views, ${ }^{2}$ but debate in those terms has proved inconclusive. Behind the legal bickering, a complex, but unstated, operational $\operatorname{code}^{3}$ has

* Wesley N. Hohfeld Professor of Jurisprudence, Yale University; Board of Editors. The author acknowledges contributions of Myres S. McDougal, Andrew R. Willard and Allison M. Zieve.

${ }^{1}$ See, e.g., National Security Act of 1947,10 U.S.C. $\$ 133($ a) (1982) (readiness status of NATO military forces); 10 U.S.C. $\$ 3012(\mathrm{~b})(\mathrm{I})$ (maintenance and preparedness of army); 10 U.S.G. $\$ 8012(\mathrm{~b})(1)$ (maintenance of air force); 50 U.S.C. $\$ 401$ (1982).

"See, e.g., E. V. Rostow, "Once More unto the Breach": The IVar Powers Resolution Revisited, 21 VAL. U.L. REV. 1, 3-7 (1986); R. TURNER, THE WAR POWERS RESOlUTION: ITS IMPLEMENTATION IN Theory AND Practice 16-18 (1983); T. Reveley, War Powers of The PresiDENT AND CONGRESS 170-75, 227-28 (1981); Franck, After the Fall: The New Procedural Frameurork for Congressional Control over the IVar Pou'er, 71 AJIL 605, 607-08 (1977); Koh, Why the Prestdent (Almost) Always Wins in Foreign Affairs: Lessons of the Iran-Contra Affair, 97 YALE L.J. 1255 (1988).

${ }^{x}$ By operational code is meant a set of norms that operate in a certain sector and that actors deem to be authoritative even though the norms may be inconsistent with formal legal codes. The operational code is normative but is inferred from past practice and projections of future trends, rather than from documents alone. See generally W. M. REISMAN, FOLDED LIES (1979); W. M. REISMAN \& A. WILlaRd, INCIDENTS: ThE LAW ThaT COUNTS IN INTERNATIONAL Politics (1987). 
developed, allocating competence to initiate, direct and terminate different types of coercion among the branches. Parts of the operational code are clear and relatively stable over time. Other parts are less certain and can be projected only with qualifications, reservations or contingencies.

Understanding the distribution of war powers is a practical and urgent matter. Allies and adversaries must know when and how each will respond to which events if common defense and reciprocal deterrence are to be effective. Symbolic uses of force-like conspicuously changing the level of alert, sending a wing of fighter-bombers to a beleaguered country, positioning an AWACS, or conducting joint or separate maneuvers or war gatmes-are standard pieces in the political repertory, used as protest or warning, for conservation, deterrence or expansion of power. The effectiveness of these symbolic uses of force depends on credibility. For democratic governments, credibility depends in key part on whether the internal process is, and is believed to be, capable of making good on commitments.

I propose to examine, first, why the entire matter has proved intractable; second, what the contents of the code are; and third, the extent to which the operational code that has emerged meets contemporary constitutional requirements.

\section{Why the Problem Continues}

\section{Lack of Clarity in the Original Scheme}

The general U.S. constitutional technique of checks and balances was designed to limit, if not disable, the federal Government. Power was checked and balanced by dividing functions among the different branches. Foreign affairs functions were centralized in the federal Government and their various sequential components were distributed among the branches. ${ }^{4}$ The President is the commander in chief of the war-making mechanism. ${ }^{5}$ The competence to initiate its plenary use, and thus to engage the nation in the activity, is assigned to Congress. ${ }^{6}$

The Constitution speaks only of "war,"7 not mentioning the range of lesser coercion involving the symbolic or actual use of armed force. The document is unclear as to whether the Framers intended the word "war" as a generic term for all purposive violence or whether they understood that the commander in chief would retain independent competence to initiate and engage in coercion short of war.

\section{Radical Contextual Changes}

The conditions that prevailed in 1789 have changed radically, with regard to the United States, the world and the U.S. role in it. Foreign relations generally and armed conflict in particular play a so much greater and more

${ }^{4}$ See U.S. ConST. Art. I, §8, cls. 1, 3, 11; id., Art. I, §10; id., Art. II, §2; id., Arı. III, §2. See THE FEDERALIST Nos. 48 (J. Madison), 51 (A. Hamilton or J. Madison), and 73 (A. Hamilton). ${ }^{5}$ U.S. CoNST. Art. II, $\$ 2$.

${ }^{6}$ Id., Art. I, §8, cl. 11.

${ }^{7} I d$. 
continuous role in domestic life that even if the tacit interbranch arrangements forged in the 18th and 19th centuries had continued, executive power would still have been aggrandized at the expense of the other branches.

Nuclear weapons have decisively changed military reality and international relations. Chemical, biochemical and bacteriological weapons may push the changes further in the next century. Until 1945, wars could be anticipated and prepared for, national debates could be conducted or, at least in the case of the two world wars, public opinion could be prepared. Hiroshima ushered in the era of the "come as you are" war. Because wars could start and end quickly, actions aimed at staving off widespread conflict might have to be taken rapidly. Thus, military technology transformed the world arena from one of episodic to permanent militarization, with vast competing organizations maintaining an infrastructure of vigilant, planetary-wide surveillance, rapid positioning and deployment, and continuous weapons research and development, all in an increasing spatial arena. ${ }^{8}$

Domestically, war, instead of a periodic evanescent episode in American life, became a continuing political, psychological and financial preoccupation, with a claim to defer or depreciate in varying degree other key rights and liberties. Because foreign affairs was invading and subordinating domestic affairs, whoever called the tune in foreign affairs increasingly called it in domestic matters. ${ }^{9}$ The increasing interdependence of nations and, hence, the permeability of the line supposedly dividing domestic from international political issues came to mean that every policy and every strategic option had discernible and substantial impact on different domestic regions or interest groups.

When the War Department was renamed the Defense Department, ${ }^{10}$ the change was more than nominal. The entire sector was growing and becoming institutionalized in an unprecedented way. Henceforth, parts of the defense establishment, now planning and pre-positioning on a global scale, would insist on operating with a high degree of "security." Coordinately, the "intelligence community" began to develop its own operational capacity. In short, more governmental entities, with their own security concerns and bureaucracies, began to involve themselves in the regular planning for, and use of, force in international politics.

National interests became global. Industrial and science-based civilizations, incorporating large numbers of interdependent states, required assured access to vital materials, some found only in areas beyond national control. Every part of the planet was assigned some geo-military and geoeconomic valence. In this calculus, changes in political control over even distant parts of the planet suddenly became critical for domestic economic vigor and national military security.

"For background, see Reisman, Private Armies in the Global War System: Prologue to Decision, 14 VA. J. INr'L L. 1 (1973); McDougal, Reisman \& Willard, The Effective Power Process, 21 U.C. DAVIS L. REV. 807 (1988).

"See Manning, Congress, the Executive and Intermestic Affairs, 55 FoREIGN AFF. 306 (1977).

ii) See National Security Act of 1947, 10 U.S.C. $\$ \$ 131-133$ (1982). 
Neither the United Nations Charter nor the nuclear stalemate stopped the use of force in international politics. Under the nuclear umbrella, big, long wars may be the exception; but the actual and symbolic use of force is more common than ever. "Resort to armed force," Lord McNair lamented, "is widespread and constant, but none dare call it "war'."1 The nuclear weapons in reserve limit the extent of political change and, in an unexpected way, make the world "safer" for conventional war. Ironically, this situation hastened the obsolescence of the literal allocation of war powers under the Constitution; for if actors were less and less likely to declare wars they were more and more likely to use force, in one form or another. Foreign policy decisions, many ultimately turning on the intense use of force, came to be made continuously, and often rapidly and discreetly or secretly.

\section{National Constitutive Changes}

When lawyers study the American political system through time, they tend to adopt as their frame of reference the Constitution, a document describing the creation of a set of institutions in 1789. Even adding the plethora of agencies that have since been formally appended, one still receives an incomplete picture of the actual processes of the national community that establish and maintain the fundamental institutions for making decisions: the constiturive process. ${ }^{12}$

The document of 1789 does not account for such things as the extraordinary growth of national, regional and local media as a factor shaping popular perceptions of what is occurring and whether or not it is right. The growth, independence and influence of this estate coincided with a breakdown of the reciprocal restraints practiced by the federal Government and the media in earlier periods of national crisis. National party :structures, which were an effective technique for maintaining discipline within the legislative branch, have also eroded. The possibilities of a bipartisan foreign policy once depended upon party leaders capable of keeping party members in line. That capacity has decayed. Nor does the 1789 document take account of the continuing high degree of effectiveness of business interests in American politics and the operation of bureaucratic dynamics generating departmental interests and competition.

Unprecedented demographic and political changes in the United States in the last century and, in particular, changes in the cohesion of the national elite now permit more and more groups with highly focalized interests to influence national policy. The composition of the foreign policy elite in the United States, once a relatively small regional group shaped by an intense process of acculturation, has also been diffused over the past half-century. One result is a less coherent conception of national interest. All of these developments are facilitated by the ideology that national interest is not a consistent, rational and objectively verifiable collective choice but a self-

$"$ A. MCNair, THE Legal Effects of WAR, at vii (4th ed. 1966).

${ }^{12} \mathrm{McD}$ ougal, Lasswell \& Reisman, The World Constitutive Process of Authoritatiz' Decision, in M. S. McDougal \& W. M. Reisman, International Law EsSays 191 (1981). 
generating chorus, constituting and organizing itself, without direction, from its members' discordant shouts of self-interest.

\section{Aggravation of Interbranch Relations}

A constitutional common law developed early with regard to the use of force short of war. The President used the military instrument at his disposal in a variety of settings in which war had not been declared and for which the Senate or Congress as a whole had not voted specific authorization $^{13}$ (much as the President developed a parallel agreement-making procedure that bypassed the Senate $\left.{ }^{14}\right)$. Congress, as a whole, rather than being an obstacle and competitor to the Executive's expanded role in foreign policy, was often accommodating and compliant. ${ }^{15}$ That trend was matched and validated by the judiciary. ${ }^{16}$

After World War II, this de facto accommodation, which had suffered episodic stresses, began to disintegrate, with a series of abortive war powers resolutions, ${ }^{17}$ increasing congressional efforts to assert control over agreement making, ${ }^{18}$ and more direct intervention in diplomatic protection. ${ }^{19}$ Congress, for example with regard to Cuba in 1962, sometimes urged a reluctant or vacillating Executive to apply force short of war. ${ }^{20}$ During the Vietnam War, the weakening of party discipline at the national level and the disintegration of a bipartisan foreign policy exacerbated divisions between

\footnotetext{
"R. TURNER, supra note 2, at 23-32.

14 See McDougal \& Lans, Treaties and Congressional-Executive or Presidential Agreements: Interchangeable Instruments of National Poligy, in M. S. MCDOugal \& Associates, STUdies IN WORLD PUBLIC ORDER 404, 412 (1987).

${ }^{15}$ Since and including the landmark case of United States v. Curtiss-Wright Export Corp., 299 U.S. 304 (1936), most of the cases reviewed by the Supreme Court in which a purported violation by the Executive of congressional power over foreign affairs took place were not initiated by Congress (which apparently would have let the matter pass), but by private parties (who felt that their interests were prejudiced and whose lawyers deemed it tactical to frame the violation in constitutional terms). See, e.g., Youngstown Sheet \& Tube Co. v. Sawyer, 343 U.S. 579 (1952); Goldwater v. Carter, 444 U.S. 997 (1979); Dames \& Moore v. Regan, 453 U.S. $654(1981)$.

In See, e.g., Japanese Whaling Ass'n v. American Cetacean Soc'y, 478 U.S. 221 (1986); Dames \& Moore v. Regan, 453 U.S. 654 (1981); Haig v. Agee, 453 U.S. 280 (1981); Goldwater v. Carter, 444 U.S. 997 (1979); Chicago \&. S. Air Lines v. Waterman S.S. Corp., 333 U.S. 103 (1948); United States v. Pink, 315 U.S. 203 (1942).

17 See debates on S. Res. 99, 82d Cong., 1st Sess., 97 CONG. REc. 2539, 2571, 2589, 2644, $2652,2736,2739,2769,2845,2851,2862,2871,2903,2910,2938,2966,3008,3041$, 3056, 3062, 3076, 3144, 3161,3254 (1951); see also H.J. Res. 9, 82d Cong., 1st Sess., 97 Cong. ReC. 34 (1951); S. ReP. No. 129, 91 st Cong., 1st Sess. (1969); 115 CONG. REC. 17,245 (1969) (National Commitments Resolution).

${ }^{1 *}$ See S.J. Res. 130, 82d Cong., 2d Sess. (1952); S.J. Res. 1, 83d Cong., 1st Sess. (1953); S.J. Res.73, 83d Cong., 1st Sess. (1953); S. REP. No. 412, 83d Cong., 1st Sess. (1953) (Bricker Amendment).

${ }^{14}$ See, e.g., Foreign Operations, Export Financing, and Related Programs Appropriations Act, 1988, Pub. L. No. 100-202, tit. II, $\S 5542,569,570,577$, 101 Stat. 1329, 1342-44, 1365 , 1373-74, 1379-80 (1987).

2"G. Allison, Essence of Decision: Explaining the Cuban Missile Crisis 194-95 (1971).
} 
Congress and the Executive. Although U.S. participation in that conflict was authorized by a theoretically rescindable ${ }^{21}$ congressional resolution, ${ }^{22}$ members of Congress became concerned by what they saw as an erosion of their power in international relations. It is no surprise that this period witnessed the enactment of both the War Powers Resolution:3 and the Case-Zablocki amendment, ${ }^{24}$ which purported to narrow asserted executive powers in, respectively, use of force and agreement making. These developments occurred at the nadir of executive-congressional relations in this century. The War Powers Resolution was passed within weeks of the "Saturday Night Massacre,"25 without which it might well have fared no better than its predecessors.

Even in its early and relatively vigorous years, the Resolution proved to be narrower in practice ${ }^{26}$ than envisaged. ${ }^{27}$ Successive administrations have resisted it, ${ }^{28}$ and the Supreme Court has cast doubts on the constitutionality of one of its fundamental mechanisms. ${ }^{29}$

\section{The Operational Code of War Powers}

The operational code allocating competence to use force abroad is complex and opaque in places. The code is unstable because each Executive continues to insist on broad, independent competence to use force as it feels events require, while Congress insists on what it deems its prerogatives. But

${ }^{21}$ Gulf of Tonkin Resolution, Joint Resolution of Aug. 10, 1964, H.R.J. Res. 1145, 88th Cong., 2d Sess., 78 Stat. 384, repealed by Act of Jan. 12, 1971, Pub. L. No. 91-672, \$12, 84 Stat. 2053.

${ }^{22}$ See, e.g., The War Powers Act: Hearings Before the Senate Comm. on Foreign Rilations, 93d Cong., 1st Sess. 23-25 (1973) (Statement of Nicholas deB. Katzenbach); see also STAFF of Senate Comm. on Foreign Relations, 91st Cong., 2D Sess., Documents Rillating to the War Power of Congress. THE President's Authority as Commander-IN-Chief AND THE WAR IN INDOCHINA 1-7 (Comm. Print 1970) (Statement of Nicholas deB. Katzenbach in opposition to National Commitments Resolution).

${ }^{23} 50$ U.S.C. $\S \S 1541-1548$ (1982). $\quad{ }^{24} 1$ U.S.C. $\$ 112 b(1982)$.

.${ }^{25} \mathrm{See}$ T. Eagleton, War and Presidential Power 213-20 (1974).

${ }^{26}$ Unlike the Constitution, the Resolution refers to force in broad terms, to include "assignment of members of such armed forces to command, coordinate, participate in the movement of, or accompany the regular or irregular military forces of any foreign country or government when such military forces are engaged, or there exists an imminent threat that such forces will become engaged, in hostilities." 50 U.S.C. $\$ 1547(c)$ (1982). The legislative history indicates, "The word hostilities was substituted for the phrase armed confict . . ." H.R. REP. No. 287, 93d Cong., Ist Sess. 7 (1973).

${ }^{27}$ Phillip Zelikow has compiled from public records 44 instances of the use of armed force abroad by the United States from 1975 to $1982,88 \%$ of which, he concluded, had favorable outcomes in relation to the objectives of the U.S. decision makers. In the same period, the War Powers Resolution was invoked nine times, of which only five involved types of incidents for which it was intended.

${ }^{28}$ See Executive statements reporting on uses of force, reprinted in U.S. NAVAL WAR Cól. Lege, The 1973 War Powers Resolution: Law and PRACTice, Tab D; Glennon, The War Powers Resolution Ten Years Later: More Politics than Law, 78 AJIL 571, 572-75 (19134).

${ }^{29}$ INS v. Chadha, 402 U.S. 919 (1983). 
practically, Congress cannot be consistent. Congress has to endorse and possibly applaud executive actions that it feels are sound, or that succeed, or that enjoy popular support, which creates precedents and undermines its position for those occasions when it actively opposes an executive action.

The following propositions reflect, in my view, the expectations of effective actors, domestic and foreign, about the way national competence to use force is distributed.

1. War, in its traditional international legal and constitutional sense, may only be declared by Congress. The operational code assigns preponderant power to the Executive for the initiation of action but, in comparison with the past, somewhat greater power to Congress in its implementation and termination.

2. Reactive nuclear war is a matter of presidential competence. Ambiguities as to what is reactive and what proactive-e.g., an increase to a high level of alert, which itself heightens risk-will enhance executive competence. ${ }^{30}$

3. Other overt military actions short of national war are matters of initial presidential competence, subject to a condition subsequent: continuing congressional political support.

4. As regards low-level, protracted ground operations requiring repeated congressional allocations, Congress will enjoy broader power in defining their scope, somewhat less in their termination and virtually none in their initiation. There will be more consultation between the Executive and Congress, but it may not qualify as "consultations" under the War Powers Resolution and the influence it actually allows will be difficult to gauge.

5. Military maneuvers designed to convey commitment to allies or contingent threats to adversaries-e.g., repositioning part of the fleet, symbolic visits of a wing of fighter-bombers, interposition of AWACS or a manifest increase in alert level - are matters of presidential competence. Congress does not appear to view as within its bailiwick many low-profile contemporary expressions of gunboat diplomacy, i.e., the physical interposition of some U.S. war-making capacity as a communication to an adversary of United States' intentions and capacities to oppose it. For constitutional comity, however, the Executive will make a point of notifying and consulting congressional leaders in most cases.

6. In the wider constitutive process, the public's attention span and tolerance vis-à-vis uses of military force, short of a massive attack on U.S. territory, will be directly proportional to the loss of American lives in the action, factored by its duration. For reasons that are obscure, ground commitments will be less tolerable than naval commitments.

7. Courts will steer clear of future war powers confrontations, which will be resolved politically.

\footnotetext{
${ }^{30}$ See generally P. Bracken, The Command and Control of Nuclear Forces (1983). Even proponents of strong congressional competence acknowledge the President's competence in the strategic area. See, e.g., Franck, supra note 2, at 607-11. Rostow has criticized Franck in this regard but is not persuasive. Rostow, supra note 2, at 48-50.
} 
8. This new constitutive regime will have a discernible limiting effect on the tactical choices available to the military. ${ }^{31}$ One alternative to this limit, developed by President Nixon and Secretary Kissinger, adopted belatedly by President Carter and refined by President Reagan, has been proxies. (The Imperial Government of Iran, for example, operated as a proxy for the United States; its collapse indicates the inherent dangers of the scheme.) Not all potentially effective proxies will prove acceptable in domestic politics. $^{32}$

9. Executive programs to mount larger mobilizations and involvements may be facilitated by and may capitalize on accidental variables: external precipitating event(s), e.g., Pearl Harbor and the more trivial, but emotiongenerating, Gulf of Tonkin affair. However, even when the popular temper is outraged by a dramatic act of violence, the injunction of haste under the sixth proposition above will hold. The longer an action persists, the more time there will be for opposition to mobilize and drain support, undermining the executive-initiated national effort.

10. Executive explanations to the rank and file are likely to become simpler, even to the point of being ludicrous. Part of this may be attributable to the contemporary media, which tend to simplify and shorten complex and technical issues.

11. Lack of clarity in the allocation of competence and the uncertain congressional role will sow uncertainty among those who depend on U.S. effectiveness for security and the maintenance of world order. Some reduction in U.S. credibility and diplomatic effectiveness may result. Alliance patterns will adjust accordingly.

\section{Does the Operational Code MEET CONSTITUTIONAL REQUIREMENTS?}

The contemporary constitutional challenge is to design or adapt institutions so that decisions about the initiation and use of coercion can be made in ways consistent with contemporary realities and historical political values. Values pertinent to this problem involve representativeness, power sharing, responsibility, effectiveness, prudence and timeliness.

Key provisions of the operational code appear inadequate in terms of these values. First, executive international effectiveness appears to have been appreciably, although not disastrously, reduced. Foreign elites often try to use Congress to deflect the Executive from a policy on which it is set. Trends in the application of the War Powers Resolution may be viewed not

\footnotetext{
${ }^{31}$ See A. Roach, A Navy Lawyer's View of the Military's Experience Under the War Powers Resolution, Remarks at the Seventh Annual Seminar of the Center for Law and National Security, University of Virginia School of Law 7, 9 (Sept. 23, 1988).

${ }^{32}$ Argentinian officers could be used directly in Nicaraguan contra operations, but South African troops could not be used in Angola. See Argentina Linked to Rise in Covert U.S. Actions Against Sandinistas, N.Y. Times, Apr. 8, 1983, at A10, col. 3; Abandon Angola to Russia?, U.S. News \& WORLD REP., Feb. 23, 1976, at 35; Angola: Dangers that Accuse Congress, id., Dec. 29, 1975 , at 19.
} 
only as communications to the President but also as messages to adversaries that persistent resistance will be rewarded rather quickly. Forceful action by the executive branch may be blunted within a relatively short time span by a Congress with its own foreign policy. ${ }^{33}$

Second, these changes influence the planning of uses of force. Planning of visible, ground-based uses of force abroad must incorporate the probability of severe time limits, no matter how urgent and valid the national interest. Alternative, short, intense, high-level actions may not always be the most economical or rational. The military also assumes that its adversary studies and targets domestic political processes, hoping that changes precipitated there will bleed support and ultimately force a change of tactics and/or policy.

Third, responsibility suffers. The institutional capacity for continuous focus on key, interrelated foreign affairs issues in immediate and larger contexts is comparatively smaller in Congress, increasing the probability of shortsighted decisions that will prove damaging in the long term. International law may suffer. Even proponents of enhanced congressional foreign affairs powers have been dismayed by Congress's cavalier disregard of international law in recent matters such as UN assessments ${ }^{\mathbf{3 4}}$ and host country obligations. ${ }^{35}$

Finally, and ironically, national representativeness may actually be reduced. Debates about war powers are frequently cast as a contest between a democratic Congress and an imperial President, the latter often conflated with a hereditary monarch on the order of George III. But in the contemporary constitutive process, the President is elected at 4-year intervals by the entire nation, largely on the basis of foreign affairs positions. The House of Representatives, whose members are chosen on local issues by subcomponents of states and, thanks to financing by political action committees, reelected at an astonishing 98 percent rate, ${ }^{36}$ could well be less nationally representative in foreign affairs than the President, who is limited to two terms and frequently turned out after the first.

\section{CONCLUSION}

A review of the operational code confirms a complex reallocation of war powers, with significant implications for the United States, as well as the rest of the world. Should the code prove ill-tooled for its tasks, the constitutive process will review it in the course of its third century, as it has in the previous two.

\footnotetext{
"3 Thus, U.S. News \& World Report stated that a "radio message between two Moslem militia units" said, "If we kill 15 marines, the rest will leave." Marines Draw a Beard on Snipers, U.S. NEWS \& WORLD REP., Oct. 31, 1983, at 13.

${ }^{34}$ See United Nations Organizations Reform in Budget Procedures, 22 U.S.C. §287e note (Supp. IV 1986).

${ }^{33}$ See, e.g., Anti-Terrorism Act of 1987,22 U.S.C.A. $\$ \$ 5201-5203$ (West Supp. 1988).

3o 46 CoNG. Q. WEeKLY ReP. 3206 (1988).
} 


\section{Nuclear WAR Powers}

\section{By Peter Raven-Hansen*}

As the Constitution enters its third century, its framework for the exercise of war powers is under siege. Presidential exercises of war powers to repel attacks, rescue lives, protect property, retaliate and threaten have posed the most persistent and visible challenge to that framework. But an equal theoretical challenge is posed by a power that the President has used only twice, the nuclear war power. ${ }^{1}$ Part I of this essay describes that challenge. Part II evaluates the constitutionality of the existing distribution of nuclear war powers. Part III identifies-but does not explore-alternatives.

I.

The contours of the original constitutional war powers framework are well-known. ${ }^{2}$ The Framers conferred on Congress the power to decide war or peace by formal declaration or other authorization. They also recognized that the decision may be made for us by an enemy attack creating a state of general war and a threat to the national security that the President must repel without awaiting congressional authorization. In either case, they vested the command of the armed forces in the President, acknowledging the efficiencies of a single commander in chief. Finally, they left Congress both the antecedent control of establishing and regulating the forces that the commander in chief has to command and the subsequent control of appropriating funds for their continued support in the field. At a time when the nation had no standing army, pre-positioning of military forces took weeks or months, and military stockpiles were too small to sustain forces in the field for long, these controls assured that Congress would hold the reins on the dogs of war.

The development of nuclear weapons has turned this framework on its head. The existing stockpile of nuclear weapons can incinerate the earth several times over. They are already pre-positioned, in that land-based missiles can be delivered on target in 30 minutes, and submarine-based missiles in even less time. ${ }^{3}$ The combination of these characteristics-vast destructive potential and speed of delivery-can bring us precipitately to what National Security Adviser Scowcroft calls "the automatic phase of war,"

\footnotetext{
* Professor of Law, George Washington University National Law Center.

' See generally First Use of Nuclear WeApons: UNDER the CONSTITUTION, Who DECIDES? (P. Raven-Hansen ed. 1987) [hereinafter WHO DECIDES?]; NuCLEAR WEAPONS AND LAW, pt. II (A. Miller \& M. Feinrider eds. 1984); Goldstein, The Failure of Constitutional Controls Over War Powers in the Nuclear Age: The Argument for a Constitutional Amendment, 40 STAN. L. Rev. 1543 (1988); Miller \& Cox, Congress, the Constitution and First Use of Nuclear Weapons, 48 REV. OF POL. 211 and 424 (1986).

${ }^{2}$ See, e.g., L. Henkin, Foreign AfFaiRs and the Constitution 50-54, 80-81, 100-08 (1972); W .T. Reveley, WAR Powers OF THe PRESIDENT AND CoNGress (1981); A. SofaEr, I War, Foreign Affairs and Constitutional Power: The Origins, ch. 1 (1976); Lofgren, War-Making Under the Constitution: The Original Understanding, 81 YALE L.J. 672 (1972).

${ }^{3}$ See, e.g., D. FORD, THE BUTTON 132 (1985).
} 